\title{
$\begin{array}{lllllllllllllllll}\mathbf{R} & \mathbf{O} & \mathbf{Z} & \mathbf{P} & \mathbf{R} & \mathbf{A} & \mathbf{W} & \mathbf{Y} & \text { I } & \text { A } & \mathbf{R} & \mathbf{T} & \mathbf{Y} & \mathbf{K} & \mathbf{U} & \mathbf{L} & \mathbf{Y}\end{array}$
}

Prawo Kanoniczne

61 (2018) nr 1

DOI:10.21697/pk.2018.61.1.01

KS. GINTER DZIERŻON

Wydział Prawa Kanonicznego

Uniwersytetu Kardynała Stefana Wyszyńskiego

\section{WPŁYW BŁĘDU I IGNORANCJI CO DO ISTOTY AKTU PRAWNEGO NA JEGO NIEWAŻNOŚĆ (KAN. 126 KPK)}

Treść: Wstęp. - 1. Ignorancja autonomiczną wadą aktu prawnego. - 2. Błąd (ignorancja) co do istoty aktu. - 2.1. Założenia generalne. - 2.2. „Ratio legis” zasady skodyfikowanej w kan. 126 KPK. - 2.3. Nieważność aktu. - 3. Błąd (ignorancja) akcydentalny. - 3.1. Założenia generalne. - 3.2. Skarga o unieważnienie aktu. - Zakończenie.

\section{Wstęp}

W katalogu wad aktu prawnego (kan. 125 - 126 KPK) prawodawca kościelny w kan. 126 KPK określił m. in. wpływ błędu i ignorancji dotyczącego istoty aktu prawnego na jego nieważność postanawiając: „Akt dokonany pod wpływem ignorancji lub błędu dotyczącego samej istoty aktu (...) - jest nieważny, inaczej jest ważny, chyba że prawo zastrzega co innego, lecz akt dokonany pod wpływem ignorancji lub błędu może być podstawą skargi o unieważnienie według przepisów prawa”. Bezpośrednim źródłem tej regulacji jest kan. 104 CIC/17, który posiadał nieco inną treść: „Error actum irritum reddit, si versetur circa id quo constituit substantiam actus (...), secus actus valet, nisi aliud iure caveatur; sed in contractibus error locum dare potest actio rescissoriae ad normam iuris".

Zapis kan. 126 KPK stanie się przedmiotem interpretacji w tym opracowaniu. W kanonie tym ustawodawca kościelny odniósł się do dwóch kategorii wad aktu prawnego jakimi są: błąd oraz ignorancja. 
Przez błąd rozumie się mylne wyobrażenie o danym stanie rzeczy; ignorancja natomiast to niewiedza, nieznajomość danego stanu rzeczy.

Należy dodać, iż wskazana regulacja nie jest jedyną, w której prawodawca zestawił obok siebie te wady aktu prawnego. $\mathrm{Z}$ podobnym rozwiązaniem spotykamy się bowiem w kan. $15 \$ 1$ KPK dotyczącym skuteczności ustaw unieważniających i uniezdalniających w przypadku pojawienia się ignorancji lub błędu; w kan. 1323, n. 2 KPK natomiast zrównano ignorancję z błędem i nieuwagą.

Kanonistyczna zasada, o której mowa, została zaczerpnięta $\mathrm{z}$ prawa rzymskiego. Pierwotnie w tym porządku prawnym nie funkcjonowała ta reguła. Ewolucja myśli w tej materii nastąpiła pod wpływem wypracowanej przez pretorów teorii woluntarystycznej ${ }^{1}$. Dopiero w okresie klasycznym przyznano prawną skuteczność błędowi². Przy czym nie wszystkie rodzaje błędów skutkowały nieważnością podjętego działania; taki walor przypisywano tylko dwom postaciom, jakimi były: „error in substantia” oraz „error in persona”"

\section{Ignorancja autonomiczną wadą aktu prawnego}

W porównaniu do kan. 104 CIC/17 prawodawca nieco zmodyfikował brzmienie kan. 126 KPK wprowadzając oprócz błędu kategorię ignorancji. Już komentatorzy Kodeksu Pio-Benedyktyńskiego wskazywali, że zapis kan. 104 CIC/17 odnosił się również do ignorancji. Według Gomarusa Michielsa wynikało to głównie z racji praktycznych. Argumentował on, że było wolą prawodawcy, aby podejmujący działania czynili to świadomie ${ }^{4}$.

Mając na uwadze sformułowanie kan. 126 KPK rodzi się zatem zasadnicze pytanie: czy w tym wypadku należałoby mówić o dwóch

\footnotetext{
${ }^{1}$ Por. W. Rozwadowski, Error, w: Wielka encyklopedia prawa, red. B. Sitek, W. Wołodkiewicz, t. 1., Warszawa 2014, s. 179.

${ }^{2}$ Por. G. Moscarello, «Error qui versetur circa id quod substantiam Artus constituit» (can. 126). Studio storico-giuridico, Roma 2001, s. 11.

${ }^{3}$ Por. W. Litewski, Słownik encyklopedyczny prawa rzymskiego, Kraków 1998, s. 89.

${ }^{4}$ Por. G. Michiels, Principia generalia de personis in Ecclesia, Parisiis - Tornaci Romae 1955, s. 659.
} 
autonomicznych tytułach nieważności aktu prawnego wynikających zarówno $\mathrm{z}$ błędu istotnego, jak i ignorancji istotnej? Zasygnalizowana kwestia nie jest łatwa do rozstrzygnięcia. Podejmując ten wątek Michel Thèriault stwierdził, że trudno jest odróżnić ignorancję od błędu, ponieważ w praktyce ignorancja generuje błąd bądź też prowadzi do błędnej oceny rzeczywistości ${ }^{5}$. W publikacjach spotykamy pozycje, w których te wady aktu prawnego traktuje się łącznie. Takie ujęcie występuje m. in. w „Leksykonie tradycji rzymskiego prawa prywatnego" w którym Izabela Relaczyk jedno z haseł zatytułowała: „ignorantia iuris/error iuris”.

Za zróżnicowaniem zachodzącym pomiędzy ignorancją a błędem opowiedział się Francesco Falchi, zauważając, że pomimo tego, iż figury te są w pewnym stopniu do siebie podobne w obszarze nieważności aktu prawnego, to jednak mechanizmy ich powstawania nie we wszystkim ze sobą są zbieżne ${ }^{7}$. Popierając tę tezę spostrzegł on, iż nie można wykluczyć, że w przypadku aktu powziętego na skutek ignorancji elementy akcydentalne mogą być przez działającego uznane za prawnie relewantne . $^{8}$

Wydaje się jednak, iż za takim rozumieniem przemawia głównie sam zapis kan. $125 \mathrm{KPK}$, w którym ustawodawca mówiąc o ignorancji i błędzie posiłkował się alternatywą „lub” (aut).

\footnotetext{
${ }^{5}$ Por. M. Thèriault, Comento al can. 126 CIC, w: Comentario exegético al Código de Derecho Canónico, red. A. Marzoa, J. Miras, R. Rodríguez-Ocaña, t. 1, Pamplona 1996, s. 878.

${ }^{6}$ Por. I. Relaczy K, Ignorantia iuris/error iuris, w: Leksykon tradycji rzymskiego prawa prywatnego. Podstawowe pojęcia, red. A. Dębiński, M. Jońca, Warszawa 2016, s. 173.

${ }^{7}$ Por. F. FAlchi, I vizi della volontà: l'errore (can. 126 CIC) ed il dolo (can. $125 \$ 2$ CIC), w: L'atto giuridico nel diritto canonico, Città del Vaticano 2002, s. 218.

${ }^{8}$ Por. Tamże.
} 


\section{Błąd (ignorancja) co do istoty aktu}

\subsection{Założenia generalne}

Jak wiadomo, zasadniczy przedmiot uwagi w tym opracowaniu stanowi błąd (ignorancja) co do istoty aktu prawnego. W tekście łacińskim kan. 126 KPK prawodawca posłużył się określeniem błędu lub ignorancji co do substancji aktu (qui versetur id quod eam substantiam constituit). Znaczenie prawne tego łacińskiego terminu zaczerpniętego z filozofii arystotelesowsko-tomistycznej, mającego również swój odpowiednik w języku polskim, stanie się obiektem naszej uwagi.

Na marginesie należy dodać, iż prawna kategoria błędu co do substancji aktu nie jest kategorią charaterystyczną wyłącznie dla kanonicznego porządku prawnego, gdyż występowała ona już w prawie rzymskim. W tym systemie błąd, o którym mowa, dotyczył istotnych właściwości przedmiotu. Synonimem tej postaci błędu był „error in materia". Jak już wiadomo, w kanonicznym porządku prawnym ta forma błędu została przejęta właśnie z systemu rzymskiego.

Odnosząc się do kwestii substancjalności aktu, Eduardo Regatillo zauważył ogólnie, iż substancjalnym było to, co dotyczyło substancji aktu (substantialis est qui circa substantiam actus versetur) ${ }^{10}$. Komentując kan. $126 \mathrm{KPK}$, kanoniści są zgodni co do tego, iż w tym wypadku idzie o elementy konstytutywne przedmiotu aktu lub sposobu jego realizacji; chodzi więc o takie komponenty, bez których akt nie mógłby zaistniećl1 ${ }^{11}$ Po czym dopowiadają, że w zapisie interesującej nas regulacji nie idzie o substancję samą w sobie, ale o substancję odniesioną

\footnotetext{
${ }^{9}$ Por. W. Litewski, Słownik encyklopedyczny..., s. 89.

${ }^{10}$ Por. E. Regatillo, Institutiones iuris canonici, t. 1, Santander 1961, s. 173.

${ }^{11}$ Por. E. Regatillo, Institutiones..., s. 173; J. García Martín, Le norme generali del Codex Iuris Canonici, Roma 1999, s. 460; H. Pree, Allgemeine Normen, w: Münsterischer Kommentar zum Codex Iuris Canonici, red. K. Lüdicke, t. 1, Essen 1985, ad. 126, n. 3; E. Regatillo, Institutiones..., s. 173; V. De Paolis, A. D’Auria, Le norme generali di Diritto Canonico. Commento al Codice di Diritto Canonico, Roma 2008, s. 370.
} 
do aktu prawnego ${ }^{12}$. W tym wypadku nie ma znaczenia, czy byłby to błąd faktyczny, czy też błąd prawny, zawiniony bądź niezawiniony ${ }^{13}$.

Z badań przeprowadzonych przez Giovanniego Moscarello wynika, iż kategoria błędu substancjalnego nie jest jednorodna. W znaczeniu bowiem normatywnego zwrotu „qui versetur id quod eam substantiam constituit” mieści się kilka postaci błędu, jakimi są: błąd co do natury aktu (error in negotio), błąd co do przedmiotu aktu (error in corpore), błąd co do przymiotów istotnych (error in qualitatibus substantalibus) oraz błąd co do osoby (error in persona) ${ }^{14}$.

\section{2. „Ratio legis” zasady skodyfikowanej w kan. 126 KPK}

Zasada ujęta w kan. 126 KPK pozostaje w ścisłym związku z klasycznym pryncypium „nil volitum nisi praecognitum”. Zasadnicza racja wprowadzenia rozwiązania skodyfikowanego w tym kanonie wiąże się z zakłóconym procesem formacyjnym aktu w sferze intelektu. Podjęcie decyzji w porządku prawnym wymaga od osoby właściwego rozeznania i oceny przedmiotu aktu ${ }^{15}$. Błąd (ignorancja) natomiast jako wada aktu prawnego bezpośrednio godzi w sferę intelektu; pośrednio natomiast - w wolę ${ }^{16}$.

Błąd (ignorancja), o którym mowa, jest powodowany zaburzeniami intelektualnymi związanymi ze zdeformowaniem przedmiotu działania. W takiej sytuacji wola w odniesieniu do przedmiotu aktu jest wprawdzie pozytywna, ale uformowany przez nią przedmiot nie jest przedmiotem realnym ze względu na fałszywą ocenę rzeczywistości dokonaną przez intelekt.

\footnotetext{
12 Por. E. Regatillo, Institutiones..., s. 173; P. Wernz, P. Vidal, Ius canonicum, t. 2, Romae 1923, s. 41.

${ }^{13}$ Por. P. V. Pinto, De normis generalibus, w: Commento al Codice di Diritto Canonico, red. P. V. Pinto, Città del Vaticano 2001, s. 77.

${ }^{14}$ Por. G. Moscarello, Error qui versetur..., s. 182-186.

${ }^{15}$ Por. F. FAlChi, I vizi della volontà..., s. 218; R. SobAŃski, Komentarz do kan. 142 KPK, w: J. Krukowski, R. Sobański, Komentarz do Kodeksu Prawa Kanonicznego, t. 1, Poznań 2003, s. 206.

${ }^{16}$ Por. J. I. Arrieta, Commento al can. 126 CIC, w: Codice di diritto canonico commentato e leggi complementari, red. J. I. Arrieta, Roma 2014, s. 140.
} 
Ustosunkowując się do mechanizmu powstania tej wady aktu prawnego, trafnie zauważył Michiels, że w tym wypadku nie można mówić o wykluczeniu pozytywnym, lecz o wykluczeniu negatywnym $^{17}$. Nieważność aktu prawnego, o którym traktuje kan. 126 KPK, nie powstaje zatem $\mathrm{z}$ powodu intencji przeciwnej w sensie pozytywnego aktu woli, lecz z powodu defektu zaistniałego w sferze intelektualnej ${ }^{18}$; jeszcze precyzyjniej, nieważność ta nie jest następstwem błędu samego w sobie, ale następstwem zdarzenia powstałego $\mathrm{z}$ aktu podjętego pod wpływem błędu ${ }^{19}$.

\subsection{Nieważność aktu}

Z zapisu kan. 126 KPK wynika, iż nieważność aktu nie wynika z samego błędu czy ignorancji, lecz aktu dokonanego z błędu (ex errore) oraz $\mathrm{z}$ ignorancji (ex ignorantia). W doktrynie ten rodzaj błędu określa się mianem „error (ignorantia) substantialis antecedens”20. W tym wypadku bowiem błąd (ignorancja) staje się przyczyną sprawczą nieważności aktu (error causam dans) ze względu na to, że fałszwy obraz przedmiotu ukształtowany w intelekcie determinuje wolę. Stąd też, aby zaistniał taki skutek prawny, to powinien zaistnieć związek przyczynowy pomiędzy błędem (ignorancją) a nieważnością aktu ${ }^{21}$.

Pod rządami Kodeksu Pio-Benedyktyńskiego sprawa ta nie była do końca jasna. Brzmienie bowiem kan. 104 CIC/17 było nieco odmienne, gdyż ustawodawca stanowił: „Error actum irritum reddit, si versetur circa id quo constituit substantiam actus (...)”. Dlatego też niektórzy komentatorzy twierdzili, że nieważności aktu nie powodował jedynie „error causam dans”, ale również „error concomitans”. Uważali oni, iż nieważność aktu mogła być powodowana nie tylko działaniem „ex errore”, ale również działaniem „cum errore”. Istotnym

\footnotetext{
${ }^{17}$ Por. G. Michiels, Principia generalia..., s. 655-656.

${ }^{18}$ Por. Tamże, s. 656.

${ }^{19}$ Por. P. V. Pinto, De normis..., s. 77.

${ }^{20}$ Por. H. Pree, Allgemeine Normen, ad. 126, n. 4.

${ }^{21}$ Por. Tamże, ad. 126, n. 3.
} 
w tym wypadku było jedynie to, by wystąpił błąd substancjalny ${ }^{22}$. Taki sposób interpretacji wynikał z faktu, iż zapis „Error actum irritum reddit” posiadał charakter bardziej generalny, w porównaniu do „actus positus ex ignorantia aut ex errore” występującego w kan. 126 KPK. Takie doprecyzowanie obecnie nie pozwala już na szerszą interpretację, stosowaną przez komentatorów Kodeksu z 1917 roku.

Według Juana Ignacio Arriety następstwem wady aktu prawnego będącej przedmiotem naszego zainsteresowania jest najbardziej radykalna forma jego nieważności, jaką jest niezaistnienie aktu prawnego $^{23}$. Podobną opinię wyrazili wspominany już Moscarello oraz Eduardo Baura. Pierwszy z nich utrzymuje, iż tego typu błąd generuje nieważność w sensie braku absolutnego (carenza assoluta) ${ }^{24}$; drugi natomiast pisze, iż taki błąd kompletnie burzy wolę (completamente dissolvono la volontà $)^{25}$. Twierdzenia tych uczonych są koherentne z paremią Dioklecjana: „Działający pod wpływem błędu nie ma woli” (errantis voluntas nulla est) ${ }^{26}$. Kanoniści stoją na stanowisku, iż nieważność aktu prawnego, o której traktuje kan. 126 KPK, wynika $\mathrm{z}$ prawa naturalnego ${ }^{27}$.

Z bezpośrednią aplikacją tej zasady w odniesieniu do błędu spotykamy się w dwóch zapisach kodeksowych, jakimi są: kan. 188 KPK, zgodnie z którym rezygnacja dokonana na skutek błędu substancjalnego jest nieważna, oraz kan. $1097 \$ 1 \mathrm{KPK}$, dotyczący błędu co do osoby.

Tak radykalnych skutków nie powoduje błąd (ignorancja) akcydentalny.

\footnotetext{
${ }^{22}$ Por. G. Michiels, Principia generalia..., s. 656.

${ }^{23}$ Por. J. I. Arrieta, Commento al can. 126 CIC, s. 140.

${ }^{24}$ Por. G. Moscarello, «Error qui versetur..., s. 182.

${ }^{25}$ Por. E. Baura, Lezioni di diritto canonico. Parte generale, tłum. G. Comotti, Venezia 2010, s. 130.

${ }^{26}$ Por. C. $1,18,8$.

${ }^{27}$ Por. E. Regatillo, Institutiones..., s. 173; G. Moscarello, Error qui versetur..., s. 182.
} 


\section{Błąd (ignorancja) akcydentalny}

\subsection{Założenia generalne}

W przeciwieństwie do błędu (igonorancji) błąd (ignorancja) o charakterze akcydentalnym nie skutkuje nieważnością aktu. W takiej sytuacji więc podjęty przez osobę akt jest ważny ${ }^{28}$. Michiels twierdził, iż w tym wypadku ważność aktu jest oczywista, ponieważ błąd akcydentalny nie godzi w substancję aktu; w tym wypadku bowiem substancja aktu jest pozytywnie chciana przez osobę działającą ${ }^{29}$. Poruszając tę kwestię, Francesco Falchi napisał, że takie błędy nie znoszą zdolności decyzyjnej podmiotu ${ }^{30}$.

$\mathrm{Z}$ bezpośrednią aplikacją tej zasady spotykamy się w kan. $66 \mathrm{KPK}$, w którym zapisano, iż nieważności reskryptu nie powoduje błąd co do takich elementów akcydentalnych, jak: nazwisko osoby zarówno tej, która go udzieliła, jak i tej, która go otrzymała, miejsca zamieszkania odbiorcy oraz samej sprawy, o którą chodziło pod warunkiem, że według ordynariusza nie było żadnej wątpliwości co do samej osoby lub sprawy.

Przy tym należy zauważyć, iż prawodawca kościelny jednak nie wyklucza odmiennych rozwiązań. Dlatego też w kan. 126 KPK znalazła się klauzula: „chyba, że prawo zastrzega co innego” (nisi aliud iure caveatur). Według Thèriaulta przyzwolenie na taką ewentualność wynika $\mathrm{z}$ faktu, iż z podjęcia takiego aktu może wyniknąć szereg negatywnych następstw ${ }^{31}$.

W obowiązującej kodyfikacji występują wyjątki od tej zasady generalnej. I tak po pierwsze, we wspomnianym już kan. $15 \$ 1$ KPK postanowiono, że ignorancja lub błąd co do ustaw unieważniających i uniezdalniających nie przeszkadzają ich skutkom; po drugie; w kan. $1097 \$ 2$ KPK dotyczącym błędu co do przymiotu osoby; po trzecie,

\footnotetext{
${ }^{28}$ Por. J. García Martín, Le norme generali..., s. 461; R. Sobański, Komentarz do kan. 142 KPK, s. 207.

${ }^{29}$ Por. G. Michiels, Principia generalia..., s. 658.

${ }^{30}$ Por. F. FAlchi, I vizi della volontà..., s. 220.

${ }^{31}$ Por. M. Thèriault, Comento al can. 126 CIC, s. 879.
} 
w kan. 1098 KPK odnoszącym się do wpływu podstępu na ważność umowy małżeńskiej; po czwarte, w kan. 1099 KPK, w którym ujęto wpływ błędu prawnego na ważność zawartego małżeństwa oraz po piąte, w zapisie kan. $1616 \$ 1 \mathrm{KPK}$, w którym traktuje się o błędzie w treści wyroku ${ }^{32}$.

\subsection{Skarga o unieważnienie aktu}

Jak wiadomo, akt dokonany pod wpływem błędu (ignorancji) akcydentalnej jest ważny. W tym wypadku jednak prawodawca stworzył możliwość wniesienia skargi o unieważnienie aktu. Wprowadzenie takiego rozwiązania wynika stąd, że z punktu teoretycznoprawnego idzie o akty unieważnialne. Przy czym, rozwiązanie to nie może być stosowane do węzła małżeńskiego, który nie ma takiego charakteru.

Pod rządami Kodeksu Pio-Benedyktyńskiego problem actio rescissoria rozważano wyłącznie w odniesieniu do kontraktów ${ }^{33}$. Taki sposób podejścia był zupełnie zrozumiały, ponieważ w zapisie kan. 104 CIC/17 występowało wyraźne odniesienie do tej kategorii ${ }^{34}$. Obecnie w kan. 126 KPK nie mówi się o kontraktach; jego zapis jest bardziej generalny, dlatego też można go stosować do wszelkich aktów prawnych. Jego „ratio legis” wynika z faktu, iż chociaż powzięto akt co do elementów akcydentalnych, to jednak jest on aktem wadliwym ${ }^{35}$.

Komentując kan. 126 KPK, Helmut Pree spostrzegł, iż w obowiązującym porządku prawnym stworzono możliwość unieważnienia aktu w odniesieniu do aktów administracyjnych. I tak w kan. 149 $\$ 2$ KPK postanowiono, iż powierzenie urzędu kościelnego osobie, która nie posiadała przymiotów wymaganych do ważności, może być cofnięte dekretem kompetentnej władzy lub wyrokiem trybunału

\footnotetext{
${ }^{32}$ Por. R. Sobański, Komentarz do kan. 142 KPK, s. 207.

${ }^{33}$ Por. W. Aymans, K. Mörsdorf, Kanonisches Recht, t. 1, Padeborn-MünchenWien-Zürich 1991, s. 349.

${ }^{34}$ Por. P. Wernz, P. Vidal, Ius canonicum, s. 42; G. Michiels, Principia generalia..., s. 659; E. Regatillo, Institutiones..., s. 173.

${ }^{35}$ Por. H. Pree, Acto jurídico, w: Diccionario general de derecho canónico, red. J. Otaduy, A. Viana, J. Sedano, t. 1, Pamplona 2012, s. 176.
} 
administracyjnego; poza tym, w kan. $166 \$ 2$ KPK zapisano, że kompetentna władza może unieważnić wybór na wniosek pominiętego wyborcy ${ }^{36}$.

Należy też zauważyć, iż w obowiązującym Kodeksie nie znalazły się regulacje prawa formalnego odnoszące się do wniesienia skargi o unieważnienie aktu, które znajdowały się w Kodeksie z 1917 roku (kan. 1684-1689 CIC/17) ${ }^{37}$. Do tego problemu Remigiusz Sobański proponuje pewne rozwiązania. Mianowicie, zwrócił on uwagę, iż w przypadku wniesienia takiej skargi trzeba udowodnić zaistnienie związku przyczynowego pomiędzy błędem a podjętym przez osobę aktem $^{38}$.

\section{Zakończenie}

Prezentowana zasada ujęta w kan. 126 KPK w obszarze skutków odbiega nieco od tej, która została skodyfikowana w kan. $125 \$ 2$ KPK dotyczącym wpływu podstępu i bojaźni na ważność aktu prawnego. Zasadnicza różnica bowiem polega na tym, że w pierwszym przypadku akt jest nieważny; w drugim przypadku natomiast jest ważny. Odnosząc się do tej kwestii, Winfrid Aymans i Klaus Mörsdorf stoją na stanowisku, iż pomiędzy tymi rozwiązaniami istnieje pewien brak równowagi ${ }^{39}$. Argumentując wskazali oni, iż taki stan teoretycznoprawny wynika z faktu, że wadliwość aktu dokonanego pod wpływem bojaźni lub podstępu można łatwiej udowodnić; inaczej ma się rzecz z błędem (ignorancją), którego wadliwość wiąże się ze sferą wewnętrzną podmiotu, bardziej konkretnie z zaburzeniami w sferze intelektu w odniesieniu do przedmiotu aktu.

Nie do końca można zgodzić się z tym poglądem. Wydaje się bowiem, iż racja zasady skodyfikowanej w kan. $125 \$ 2$ KPK jest inna. Jak wiadomo, akt podjęty przez osobę pod wpływem bojaźni lub

\footnotetext{
${ }^{36}$ Por. H. Pree, Allgemeine Normen, ad. 126, n. 4.

${ }^{37}$ Por. C. Redaelli, Commento al can. 126 CIC, w: Codice di diritto canonico commentato, Milano 2017, s. 174.

${ }^{38}$ Por. R. Sobański, Komentarz do kan. 142 KPK, s. 207.

${ }^{39}$ Por. W. Aymans, K. Mörsdorf, Kanonisches Recht, s. 350.
} 
podstępu jest ważny. Prawodawca jednak stworzył możliwość rozwiązania tego aktu. W myśl doktryny, przyzwolił na taką ewentualność, ponieważ została naruszona zasada sprawiedliwości. Tym sposobem pragnie on chronić tych, którzy zostali pokrzywdzeni. W tych właśnie przesłankach należy upatrywać zasadniczej „ratio legis” tej normy.

Wydaje się, iż inny powód zadecydował o wprowadzeniu zasady skodyfikowanej w kan. 126 KPK; w tym wypadku zadecydowały o tym racje teoretycznoprawne o podłożu ontologicznym w rozumieniu filozoficznym arystotelesowsko-tomistycznym. Otóż zniekształcenie przedmiotu aktu w jego elementach istotnych będące następstwem błędu (ignorancji) substancjalnego z natury rzeczy nie może generować innych skutków, jak tylko nieważność aktu.

Patrząc na to zagadnienie $\mathrm{z}$ ukazanej perspektywy, trudno jest opowiedzieć się za tezą, iż pomiędzy kan. $125 \$ 2$ KPK i kan. 126 KPK istnieje brak równowagi. O skodyfikowaniu bowiem tych zasad zadecydowały nieco odmienne powody.

\section{The impact of error and ignorance about the substance of a legal act on its invalidity(can. $126 \mathrm{CIC}$ )}

In the presented article, the author's attention has become the interpretation of can. $126 \mathrm{CIC}$ regarding the influence of error and ignorance about the substance of a legal act on its invalidity. He proved that error and ignorance are autonomous flaws of a legal act. In the final part of his study, arguing against the views of Winfried Aymans and Klaus Mörsdorf who believed that there is a certain kind of imbalance between can. $125 \$ 2$ CIC (in which the impact of deceit and fear on the validity of a legal act was codified) and can. $126 \mathrm{CIC}$, he expressed the opinion that such a claim is unjustified. According to the author, other reasons were decisive for codifying these principles. He claims that in can. $125 \$ 2$ CIC the legislator created an option of dissolving the act because he considered that in this case the principle of justice was violated. In this way, he aimed to protect those who have been harmed.

The author's opinion is that the introduction of the principle codified in can. 126 CL was determined by other reasons, namely theoretical-legal reasons of ontological basis in the Aristotelian-Thomistic philosophical sense. 
In his opinion, the distortion of the subject matter of an act in its essential elements resulting from a substantial error (ignorance) by nature cannot generate consequences other than the invalidity of a legal act.

SŁoWA KLUCzowE: błąd substancjalny; błąd akcydentalny; akt prawny; nieważność aktu prawnego

KEY WORDS: substantial error; accidental error; legal act; invalidity of a legal act

\section{Nota o Autorze:}

Ks. PROF. DR hAB. Ginter Dzierżon - profesor zwyczajny, kierownik Katedry Historii, Teorii i Norm Ogólnych Prawa Kanonicznego na Wydziale Prawa Kanonicznego Uniwersytetu Kardynała Stefana Wyszyńskiego w Warszawie. Autor ponad 280 opracowań z zakresu prawa małżeńskiego, norm ogólnych prawa kanonicznego oraz teorii prawa, w tym sześciu monografii. Członek Consociatio Internationalis Iuris Canonici Promovendo (Rzym) oraz Stowarzyszenia Kanonistów Polskich. 